\title{
Phytoprotection
}

\section{A note on the incidence of soilborne fungi in six crops used in rotation with potatoes}

\author{
M.J. Celetti, H. W. Johnson et H.W. Platt
}

Volume 71, numéro 2, 1990

URI : https://id.erudit.org/iderudit/705988ar

DOI : https://doi.org/10.7202/705988ar

Aller au sommaire du numéro

\section{Éditeur(s)}

Société de protection des plantes du Québec (SPPQ)l

\section{ISSN}

0031-9511 (imprimé)

1710-1603 (numérique)

Découvrir la revue

\section{Citer cet article}

Celetti, M., Johnson, H. W. \& Platt, H. (1990). A note on the incidence of soilborne fungi in six crops used in rotation with potatoes. Phytoprotection, 71(2), 97-100. https://doi.org/10.7202/705988ar
Résumé de l'article

L'incidence des champignons telluriques a été déterminée dans les tissus immédiatement sous la ligne de sol chez le trèfle (Trifolium hybridum et $T$. pratense), le pois (Pisum sativum), le soya (Glycine max), le ryegrass (Lolium multiflorum) cultivés en rotation avec les pommes de terre (Solanum tuberosum). Les légumineuses avaient une incidence significativement plus élevée de Verticillium albo-atrum, Colletotrichum coccodes et Fusarium solani que les graminées. Les pois avaient l'incidence la plus élevée de $V$. albo-atrum et de $F$. solani. Le $C$. coccodes a été isolé plus fréquemment du soya que du trèfle, des pois, du ryegrass, de l'orge ou du blé d'automne. Le Verticillium dahliae a été isolé de toutes les cultures, excepté le trèfle. Les graminées avaient une incidence significativement plus élevée de $V$. dahliae que les légumineuses. L'incidence du Fusarium sambucinum était plus élevée chez le soya que chez les autres cultures. Le Fusarium oxysporum a été isolé plus fréquemment du soya et de l'orge. L'incidence la plus élevée de Rhizoctonia solani a été trouvée chez le trèfle mais il a été également isolé plus fréquemment du blé d'automne et du ryegrass que du soya et de l'orge. 


\title{
A note on the incidence of soilborne fungi in six crops used in rotation with potatoes
}

\author{
M.J. Celetti \\ P.E.I. Potato Marketing Commission, clo Agriculture Canada, Research Station, \\ P.O. Box 1210, Charlottetown, P.E.I., Canada C1A $7 M 8$. \\ H.W. Johnston and H.W. Platt \\ Agriculture Canada, Research Station, P.O. Box 1210, \\ Charlottetown, P.E.I., Canada C1A 7M8. Contribution No. 667.
}

(Received 1989-09-07; accepted 1990-03-20)

\begin{abstract}
The incidence of soilborne fungi was determined in tissue immediately below the soil line of clover (Trifolium hybridum and $T$. pratense), peas (Pisum sativum), soybean (Glycine max), ryegrass (Lolium multiflorum), barley (Hordeum vulgare), and winter wheat (Triticum aestivum) grown in rotation with potatoes (Solanum tuberosum). Legume crops had significantly higher incidence of Verticillium albo-atrum, Colletotrichum coccodes, and Fusarium solani than the gramineaceous crops. Peas had the highest incidence of $V$. albo-atrum and $F$. solani. $C$. coccodes was isolated more frequently from soybean than from clover, peas, ryegrass, barley, or winter wheat. Verticillium dahliae was isolated from all crops except clover. Gramineaceous crops had a significantly higher incidence of $V$. dahliae than legume crops. The incidence of Fusarium sambucinum was higher in soybeans than all other crops. Fusarium oxysporum was isolated most frequently from soybeans and barley. The highest incidence of Rhizoctonia solani was in clover, but it was also isolated more frequently from winter wheat and ryegrass than from soybean and barley.
\end{abstract}

Celetti, M.J., H.W. Johnston, and H.W. Platt. 1990. A note on the incidence of soilborne fungi in six crops used in rotation with potatoes. PHYTOPROTECTION 71: 97-100.

L'incidence des champignons telluriques a été déterminée dans les tissus immédiatement sous la ligne de sol chez le trèfle (Trifolium hybridum et $T$. pratense), le pois (Pisum sativum), le soya (Glycine max), le ryegrass (Lolium multiflorum) cultivés en rotation avec les pommes de terre (Solanum tuberosum). Les légumineuses avaient une incidence significativement plus élevée de Verticillium albo-atrum, Colletotrichum coccodes et Fusarium solani que les graminées. Les pois avaient l'incidence la plus élevée de $V$. albo-atrum et de $F$. solani. Le $C$. coccodes a été isolé plus fréquemment du soya que du trèfle, des pois, du ryegrass, de l'orge ou du blé d'automne. Le Verticillium dahliae a été isolé de toutes les cultures, excepté le trèfle. Les graminées avaient une incidence significativement plus élevée de $V$. dahliae que les légumineuses. L'incidence du Fusarium sambucinum était plus élevée chez le soya que chez les autres cultures. Le Fusarium oxysporum a été isolé plus fréquemment du soya et de l'orge. L'incidence la plus élevée de Rhizoctonia solani a été trouvée chez le trèfle mais il a été également isolé plus fréquemment du blé d'automne et du ryegrass que du soya et de l'orge.

Commercial potato growers on Prince Edward Island, Canada, traditionally plant potatoes (Solanum tuberosum L.), once every 3 years in rotation with cereals and forage crops. In certain areas, peas (Pisum sativum L.), and occasionally soybeans (Glycine max L.), are grown in rotation with a cereal or forage crop prior to potatoes. These rotation crops are susceptible to soilborne fungi such as Fusarium solani (Mart.) Sacc., Fusarium oxysporum Schlecht. and

$\overline{0031-9511 / 90} \$ 1.00+.10$
Fusarium sambucinum Fuckel which can also cause root and tuber rot of potatoes (Cook 1981; Kraft et al. 1981). Rhizoctonia solani Kühn, the causal organism of canker and black scurf of potatoes, has a wide host range including many of the crops used in rotation with potatoes (Ogoshi 1987). Potato wilt pathogens such as Verticillium dahliae Kleb. and to a lesser extent Verticillium albo-atrum Reinke \& Berth., have been isolated from cereal and legume hosts (Evans and Gleeson 1973; Mathre 1986; Skipp et al. 1986). The effect of these rotation crops on soilborne fungi which are capable of infecting potatoes has not been clearly established. 
The purpose of this study was to assess the degree to which the rotation crops harbour soilborne fungi which may be potential pathogens of potatoes in Prince Edward Island.

Four commercial fields for each of six crops grown in rotation with potatoes were sampled in 1986 and 1987. The crops sampled were mixed clover (Trifolium hybridum L. and T. pratense L.), peas, soybeans, Italian ryegrass (Lolium multiflorum Lam.), barley (Hordeum vulgare L.), and winter wheat (Triticum aestivum L.). Thirty plants were randomly collected from each field early (November for winter wheat; May for barley, clover, ryegrass; June for peas and soybeans), mid (May for winter wheat, early July for barley, peas, and early August for clover, ryegrass, and soybeans), and late (late July for peas; early August for barley and winter wheat, and September for clover, ryegrass, and soybeans) during crop development.

Subterranean plant tissue immediately below the soil line was washed under running water for several minutes to remove soil and organic debris. Pieces of epicotyl tissue from peas, hypocotyl tissue from soybeans, crown tissue from clover, ryegrass, barley, and winter wheat were excised. Fine root pieces $(1 \mathrm{~cm})$ were also excised from the crops at each sample time. The tissue pieces were surface sterilized in a $0.6 \%$ sodium hypochlorite solution for $1 \mathrm{~min}$ followed by a $1 \mathrm{~min}$ rinse in distilled water prior to planting on isolation media. Ten pieces of each tissue and 30 root pieces from each crop were placed on 10 petri plates of three specific culture media for each isolation.

Rhizoctonia solani and Verticillium alboatrum were identified from Ko and Hora (1971) medium. Colletotrichum coccodes (Wallr.) Hughes and $V$. dahliae were isolated using the medium of Huisman and Ashworth (1974); and Fusarium spp. were isolated on potato dextrose agar (PDA) containing PCNB $(0.51 \mathrm{~g} / \mathrm{L})$. Tissue was incubated on the Ko and Hora (1971) medium for 5 days and on the Huisman and Ashworth (1971) medium for 21 days prior to identification. After 5 days Fusarium colonies were transferred from the PCNB medium to PDA containing streptomycin sulfate $(0.1 \mathrm{~g} / \mathrm{L})$ and chlorotetracycline $(0.9 \mathrm{~g} / \mathrm{L})$ and grown for 5 days under U.V. light before species identification. All media were incubated at $20^{\circ} \mathrm{C}$ until fungal identification. The percentage of incidence of fungi in each crop was recorded.

Analysis of variance and mean separation test was performed on data utilizing protected least significant differences (LSD) as a completely randomized design experiment (Snedecor and Cochran 1980) to determine the difference of fungal incidence between each crop. Arcsin transformation of data did not affect the conclusions and therefore data were analysed and presented untransformed.

Recovery of the soilborne fungi from the rotation crops was not significantly different in 1986 and 1987, therefore the means of 2 years are presented (Table 1). Although three samples were taken from each field of all crops during this study, trends were similar and only the mean percent recovery of fungi is presented to show levels and differences in the crops investigated. Legume crops had a significantly higher incidence of $V$. albo-atrum, $C$. coccodes, and $F$. solani than the gramineaceous crops (Table 1). Peas had the highest incidence of $V$. alboatrum and $F$. solani, though low levels of these fungi were isolated from all crops (Table 1). Fusarium solani f.sp. pisi (Jones) Snyder \& Hansen causes severe root rot of peas grown in Canada (Tu 1987). Colletotrichum coccodes was isolated most frequently from soybean at low incidence levels. This organism is considered only mildly virulent to potatoes, but may contribute to wilt severity and yield loss when infections occur in combination with $V$. dahliae (Scholte et al. 1985). Colletotrichum coccodes was not isolated from pea tissue.

Incidence of $V$. dahliae recovered from gramineaceous crops was at a significantly higher level than from legumes. Winter wheat had a significantly higher incidence of $V$. dahliae than ryegrass, peas, clover, and soybeans. Although $V$. dahliae was isolated from red clover roots in a study conducted by Skipp et al. (1986), this fungus was not isolated from clover roots or crown tissue on P.E.I. The host range of $V$. dahliae includes plant species from both the Leguminosae 
family (Vargas-Machuca et al. 1987, Woolliams 1966) and the Poaceae family (Evans and Gleeson 1973; Mathre 1986). This study reports the isolation of $V$. dahliae from ryegrass, a crop which is not considered a host for this fungus. No symptoms of disease which could be attributed to $V$. dahliae were observed on any of the infected plant species investigated over 2 years.

Fusarium sambucinum was recovered significantly more frequently from soybeans than from most other crops under investigation. Fusarium sambucinum has been reported to cause root rot of cereals and has also been recovered from legume crops (Booth 1971). Fusarium oxysporum was recovered more frequently from soybean than from winter wheat, ryegrass, pea, and clover. Barley, ryegrass, and clover also had a higher incidence of $F$. oxysporum than winter wheat and pea. Strains of $F$. oxysporum have been reported to cause root rot and wilt of many crops particularly legumes (Kraft et al. 1981; Skipp et al. 1986; Tu 1987). Thanassoulopoulos and Kitsos (1985) reported $10 \%$ to $53 \%$ yield reduction of potatoes caused by $F$. oxysporum f.sp. tuberosi Snyder \& Hansen infections in artificially inoculated plots.

Rhizoctonia solani was recovered significantly more frequently from clover than from any of the other crops investigated. Ryegrass also had a higher incidence of $R$. solani than either barley or soybeans. Winter wheat also supported high levels of $R$. solani. Bare patch of winter wheat and barley stunt caused by $R$. solani has been reported in several cereal growing regions of the world (Murray 1981; Weller et al. 1986). Although $R$. solani anastomosis groups AG3 and AG4 can infect and cause diseases of potatoes (Otrysko et al. 1985), $R$. solani isolates recovered from clover and barley were also found to cause stem rot of potatoes, cv. Kennebec (M.J. Celetti, unpublished data).

Certain soilborne fungi potentially pathogenic to potatoes can colonize other crops. Some of the fungi isolated from rotation crops in this study may not be damaging to

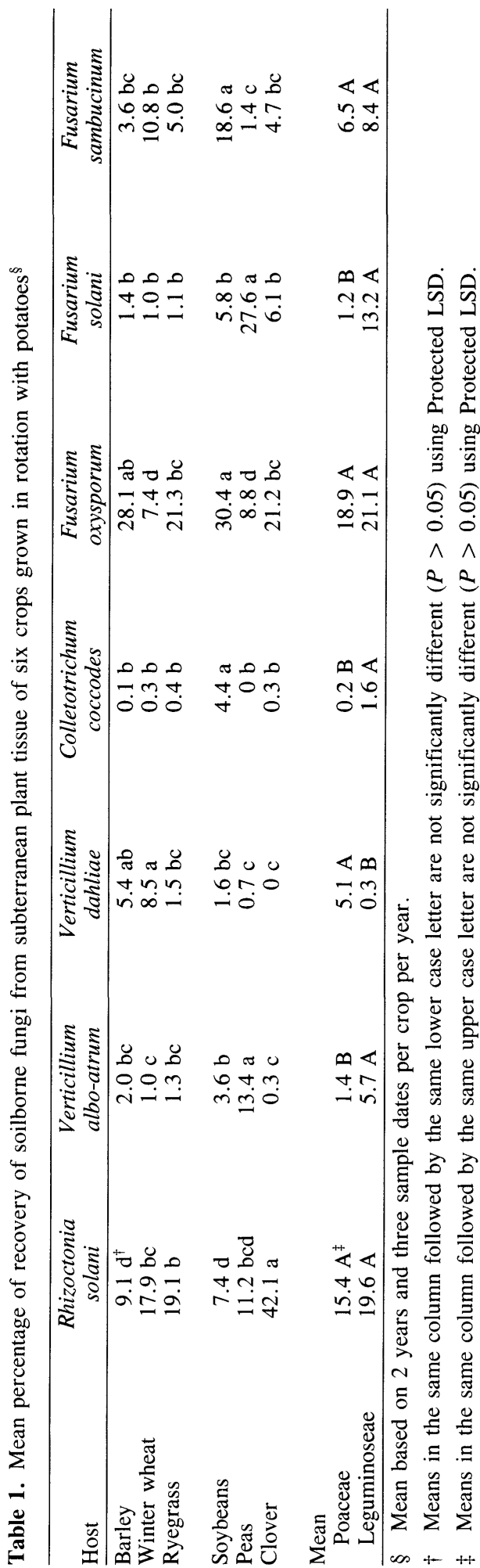


potatoes as non-pathogenic races or isolates may exist (Booth 1971). Research to determine the potential and ability of specific host strains of these fungi recovered to infect more than one crop may be required. Although many of these fungi may colonize non-host crops without causing disease, symptomless carriers may be important when considering proper crop rotation and crop sequences.

Research was funded under the P.E.I.E.R.D.A. Agreement and contracted to the P.E.I. Potato Marketing Commission. The technical assistance of Ms. M. Doucette is greatly appreciated.

Booth, C. 1971. In the genus Fusarium. Commonwealth Mycological Institute, Kew, Surrey, England, $237 \mathrm{pp}$.

Cook, R.J. 1981. Fusarium diseases of wheat and other small grains in North America. Pages 39-52 in P.E. Nelson, T.A. Toussoun, and R.J. Cook (eds.), Fusarium diseases, biology, and taxonomy. The Pennsylvania State University Press, University Park.

Evans, G., and A.C. Gleeson. 1973. Observations on the origin and nature of Verticillium dahliae colonizing plant roots. Aust. J. Biol. Sci. 26: 151-161.

Huisman, O.C., and L.J. Ashworth Jr. 1974. Quantitative assessment of Verticillium albo-atrum in field soils: procedural and substrate improvements. Phytopathology 64: 1043-1044.

Ko, W., and F.K. Hora. 1971. A selective medium for the quantitative determination of Rhizoctonia solani in soil. Phytopathology 61: 707-710.

Kraft, J.M., D.W. Burke, and W.A. Haglund. 1981. Fusarium diseases of beans, peas, and lentils. Pages 142-156 in P.E. Nelson, T.A. Toussoun, and R.J. Cook (eds.), Fusarium diseases, biology, and taxonomy. The Pennsylvania State University Press, University Park

Mathre, D.E. 1986. Occurrence of Verticillium dahliae on barley. Plant Dis. 70: 981 (Note).
Murray, D.I.L. 1981. Rhizoctonia solani causing barley stunt disorder. Trans. Br. Mycol. Soc. 76: 383-395.

Ogoshi, A. 1987. Ecology and pathogenicity of anastomosis and intraspecific groups of Rhizoctonia solani Kühn. Annu. Rev. Phytopathol. 25: 125-143.

Otrysko, B.E., G.J. Banville, and A. Asselin. 1985. Appartenance au groupe anastomotique AG3 et pouvoir pathogène d'isolats de Rhizoctonia solani obtenus de sclérotes provenant de la surface de tubercules de pomme de terre. Phytoprotection 66: 17-21.

Scholte, K., J.W. Veenbaas-Rijks, and R.E. Labruyere. 1985. Potato growing in short rotations and the effect of Streptomyces spp., Colletotrichum coccodes, Fusarium tabacinum and Verticillium dahliae on plant growth and tuber yields. Potato Res. 28: 331-348.

Skipp, R.A., M.J. Christensen, and Z.B. Nan. 1986. Invasion of red clover (Trifolium pratense) roots by soilborne fungi. N.Z. J. Agric. Res. 29: 305-313.

Snedecor, G.W., and W.G. Cochran. 1980. Statistical methods. $7^{\text {th }}$ ed. Iowa State University Press, Ames. 507 pp.

Thanassoulopoulos, C.C., and G.T. Kitsos. 1985. Studies on Fusarium wilt of potatoes. 1. Plant wilt and tuber infection in naturally infected fields. Potato Res. 28: 507-514.

Tu, J.C. 1987. Integrated control of the pea root rot disease complex in Ontario. Plant Dis. 71: 9-13.

Vargas-Machuca, R., C. Martin, and W. Galindey. 1987. Recovery of Verticillium dahliae from weed plants in farmers' fields in Peru. Plant Dis. 71: 756-758.

Weller, D.M., R.J. Cook, G. MacNish, E.N. Bassett, R.L. Powelson, and R.R. Petersen. 1986. Rhizoctonia root rot of small grains favoured by reduced tillage in the Pacific Northwest. Plant Dis. 70: 70-73.

Woolliams, G.E. 1966. Host range and symptomatology of Verticillium dahliae in economic, weed, and native plants in interior British Columbia. Can. J. Plant Sci. 46: 661-669. 